Article

\title{
Biofertilizer Production for Agronomic Application and Evaluation of Its Symbiotic Effectiveness in Soybeans
}

\author{
Aung Zaw Htwe ${ }^{1,2, *(\mathbb{D}}$, Seinn Moh Moh ${ }^{3}$, Kyi Moe ${ }^{1,2}$ and Takeo Yamakawa ${ }^{4}$ \\ 1 Graduate School of Bioresource and Bioenvironmental Sciences, Faculty of Agriculture, Kyushu University, \\ 744 Motooka, Nishi-ku, Fukuoka 819-0395, Japan; kyimoeyau@gmail.com \\ 2 Department of Agronomy, Yezin Agricultural University, Yezin 15013, Myanmar \\ 3 Department of Agriculture, Ministry of Agriculutre, Livestock and Irrigation, Yezin 15011, Myanmar; \\ hanmohmohyau@gmail.com \\ 4 Laboratory of Plant Nutrition, Department of Bioresource and Bioenvironmental Sciences, Faculty of \\ Agriculture, Kyushu University, 744 Motooka, Nishi-ku, Fukuoka 819-0395, Japan; \\ yamakawa@agr.kyushu-u.ac.jp \\ * Correspondence: aungzawhtwe333@gmail.com; Tel.: +81-80-6423-8187
}

Received: 12 February 2019; Accepted: 23 March 2019; Published: 27 March 2019

\begin{abstract}
This study was conducted to evaluate the effects of Bradyrhizobium japonicum SAY3-7, Bradyrhizobium elkanii BLY3-8, and Streptomyces griseoflavus P4 on the symbiotic effectiveness of soybeans before biofertilizer production, to produce biofertilizer containing the studied three strains (SAY3-7, BLY3-8, and P4), to test the effectiveness of the biofertilizer on soybean varieties, and to assess the varietal effects and interaction effects between variety and biofertilizer on plant growth, nodulation, nitrogen fixation, nutrient absorption, and seed yield. Nitrogen fixation was measured using the acetylene reduction assay and ureide methods. Contents of nutrients $(\mathrm{N}, \mathrm{P}, \mathrm{K}, \mathrm{Ca}$, and $\mathrm{Mg}$ ) were also measured to calculate their uptakes. In this study, synergistic effects of nitrogen fixation were induced by combined inoculation with SAY3-7, BLY3-8 and P4 in all tested soybean varieties. Therefore, we assumed that an effective biofertilizer could be produced using these effective bacteria (SAY3-7, BLY3-8, and P4). After making biofertilizer using these effective bacteria, packages were stored at $30^{\circ} \mathrm{C}$. The populations of the bacteria in the biofertilizer were maintained at a density of $1 \times 10^{8}$ colony forming units (cfu) $\mathrm{g}^{-1}$ for P4 and $7 \times 10^{9}$ cells $^{-1}$ for Bradyrhizobium. Diluting biofertilizer by $10^{-3}$ proved more effective for nodulation and nitrogen fixation than other dilution treatments. Moreover, this biofertilizer significantly promoted plant growth, nodulation, nitrogen fixation, nutrient uptakes, and seed yield in Yezin-3 and Yezin-6 soybean varieties. Yezin-6 is a more efficient variety than Yezin-3 for improved plant growth, nodulation, nitrogen fixation, nutrient absorption, and seed yield. Taken together, the application of an effective biofertilizer and the use of an efficient soybean variety can play important roles in promoting plant growth, nodulation, nitrogen fixation, and higher seed yield.
\end{abstract}

Keywords: Bradyrhizobium; Streptomyces griseoflavus; biofertilizer production; biofertilizer application; nodulation; nitrogen fixation; seed yield

\section{Introduction}

Rhizobium inoculation is a well-known agronomic practice for ensuring adequate nitrogen $(\mathrm{N})$ for legumes. Inoculating soybeans with a Bradyrhizobium strain is essential for supplying crop $\mathrm{N}$ demand and substituting for nitrogenous fertiliser. The use of biofertilizer has become a notable alternative method to chemical fertiliser. A biofertilizer is a substance containing living microorganisms that 
when applied to seeds, plant surfaces, or soil, colonise the inner part of the plant or the rhizosphere, and promote growth by increasing the supply or availability of primary nutrients to the host plant [1]. Biofertilizers are cost-effective and ecofriendly in nature. The use of biofertilizer improves soil fertility by fixing atmospheric nitrogen, solubilising insoluble phosphates, and producing plant growth-promoting substances in the soil [2]. It also promotes nodulation efficiency and increases yield by around $16-60 \%$ [3].

A group of bacteria (rhizobacteria) that lives in the rhizosphere and induces a beneficial effect on plant growth is referred to as plant growth-promoting rhizobacteria (PGPR) [4]. PGPR belong to several genera such as Azotobacter, Bacillus, Rhizobium, Bradyrhizobium, Streptomyces, and others [5], and various groups of microorganisms, including Azotobacter, Rhizobium, Azospirillum, Trichoderma, and Bacillus, are used as biofertilizers [6]. Streptomyces are known as promising biocontrol agents because of their potential to produce a wide range of secondary substances such as vitamins, alkaloids, plant growth factors, enzymes, and enzyme inhibitors $[7,8]$. Streptomyces are also known as plant growth-promoting agents [9].

Biofertilizer for soybean is mainly produced using Bradyrhizobium species, and has been distributed for domestic use for soybean production in many countries; however, it is currently not widespread in Myanmar [10]. The Plant Pathology Section of the Department of Agricultural Research (DAR), Myanmar, initiated peat-based inoculant production using exotic strains from Nitrogen Fixation for Tropical Agriculture (NifTAL) for seven legume crops [11]. These exotic strains can be replaced by indigenous strains that are adapted to local environmental conditions and have higher efficiency for nitrogen fixation. The use of indigenous rhizobia has been recommended because these bacteria adapt easily to the specific environmental conditions, facilitating their survival and successful nodulation of the host plant [12].

Many commercially available biofertilizers have been used to improve crop production efficiency worldwide [13]. However, more widespread production and utilisation of biofertilizers are required in Myanmar and in other countries. Farmers in Myanmar have a willingness to use rhizobial inoculants when sowing legumes because the cost of rhizobial inoculant application less expensive (around 150 times cheaper) than other fertilisers [14]. However, current inoculant production is lower than 100,000 packets due to limitations throughout the supply chain, from production and quality assurance to distribution to demand [10]. Therefore, much higher production of inoculants is needed in Myanmar. However, there are many factors limiting the use of rhizobia or inoculants by farmers, among which production of quality inoculants is the major concern.

Soybean plants in symbiosis with Bradyrhizobium can fix nitrogen at a rate of up to $300 \mathrm{~kg} \mathrm{~N} \mathrm{ha}^{-1}$ under favourable conditions [15]. However, the symbiosis is dependent on host specificity. This specificity may also be related to the nodulation regulatory genes of soybean cultivars and the nodulation types of rhizobia. Ishizuka et al. $[16,17]$ tested the compatibility and preference of Rj-genotype soybean cultivars with specific strains of Bradyrhizobium. The Bradyrhizobium strains were classified as nodulation types A, B, and C based on their compatibility with the Rj cultivars. Type A strains are preferred by non-Rj-genotype soybean cultivars, but nodulate with all $R j$-genotype soybean cultivars. Type B strains are preferred by $R j_{4}$-genotype soybean cultivars and inhibit nodulation with $R j_{2} R j_{3}$-genotype soybean cultivars. Type $C$ strains are preferred by $R j_{2} R j_{3}$ cultivars and restrict effective nodule formation with $R j_{4}$-genotype soybean cultivars.

Htwe et al. [18] and Soe et al. [19] reported that most soybean varieties collected from Myanmar harbour $R j_{4}$ genes and non-Rj genes. Therefore, inoculation with type A and type B strains, which prefer non- $R j$ and $R j_{4}$-genotype soybean varieties [16,17], is necessary for successful nodulation and nitrogen fixation. Our previous findings highlighted a synergistic effect of Bradyrhizobium strain with Streptomyces griseoflavus P4 in soybeans [20,21]. In both experiments, significant differences in plant growth, nodulation, $\mathrm{N}_{2}$ fixation, $\mathrm{N}$ uptake, and yield occurred in co-inoculation compared with control, but not with single inoculation of $\mathrm{P} 4$ or Bradyrhizobium strain, suggesting a synergistic effect of co-inoculation of SAY3-7 (type A) and P4 in the Yezin-6 (non-Rj) soybean variety under field 
conditions [20] and co-inoculation of BLY3-8 (type B) and P4 in Yezin-3 $\left(R j_{4}\right)$ soybean variety in the pot condition [21]. Based on the previous experiments, biofertilizer produced from sole inoculation of $\mathrm{P} 4$ or Bradyrhizobium strain is not suitable for obtaining significant effects on plant growth, nodulation, and $\mathrm{N}_{2}$ fixation. Biofertilizer production using mixed inoculants of $\mathrm{P} 4$ and Bradyrhizobium strains may be a promising method to ensure plant growth, nodulation, $\mathrm{N}_{2}$ fixation, and nutrient uptake, which support better productivity of soybeans. Therefore, this study was conducted to evaluate the effects of Bradyrhizobium japonicum SAY3-7, Bradyrhizobium elkanii BLY3-8, and Streptomyces griseoflavus P4 on the symbiotic effectiveness of soybeans before biofertilizer production, to produce biofertilizer using SAY3-7, BLY3-8, and P4, to evaluate the symbiotic effectiveness of the biofertilizer on soybean varieties during biofertilizer production, and to assess the varietal effects and interaction effects between variety and biofertilizer on plant growth, nodulation, nitrogen fixation, nutrient absorption, and seed yield.

\section{Materials and Methods}

\subsection{Expt. I. Effect of Single, Dual and Combined Inoculation of SAY3-7, BLY3-8 and P4 on Symbiotic Effectiveness of Different Soybean Varieties}

Yezin-3 $\left(R j_{4}\right)$ and Yezin- 6 (non- $R j$ ) soybean varieties were used to assess nitrogen fixation. One-litre pots were filled with vermiculite and $0.6 \mathrm{~L}$ of half-strength modified Hoagland nutrient (MHN) solution at $\mathrm{pH} 6.5$ [22]. The pots were autoclaved at $120{ }^{\circ} \mathrm{C}$ for $20 \mathrm{~min}$. Seed surfaces were sterilised by soaking seeds in $2.5 \%$ sodium hypochlorite solution for $5 \mathrm{~min}$, rinsing five times with $10 \mathrm{~mL} 99.5 \%$ ethanol, and washing five times with sterilised MHN solution. Five surface-sterilised seeds were sown in each pot. Indigenous B. japonicum SAY3-7 (type A) and B. elkanii BLY3-8 (type B) strains were obtained from a previous experiment [23]. Bradyrhizobium strains were cultured in A1E liquid medium [24] on a rotary shaker $(100 \mathrm{rpm})$ at $30^{\circ} \mathrm{C}$ for 7 days. P4 obtained from the Plant Nutrition Laboratory, Kyushu University, Japan, was incubated on IMA-2 medium [25] at $30^{\circ} \mathrm{C}$ for 5 days. For inoculation, the liquid bacterial cultures were diluted with sterilised half-strength MHN solution to $10^{5}$ cells $\mathrm{mL}^{-1}$. Each seed was inoculated with $5 \mathrm{~mL}$ of the bacterial suspension. The plants were cultivated in an environmentally controlled room $\left(25^{\circ} \mathrm{C}\right.$ and $75 \%$ relative humidity) for one month. A completely randomised design was used with three replications. This experiment was conducted from January to March 2017.

At harvest time, $\mathrm{N}_{2}$ fixation was analysed using the acetylene reduction assay (ARA) method, as described by Haider et al. [26]. To measure $\mathrm{N}_{2}$ fixation, the plants were uprooted and washed carefully with water so as to not detach the nodules. The soybean plants were cut at the cotyledonary nodes. Then, soybean roots with intact nodules were placed in a 100-mL conical flask and sealed with a serum stopper. A 25-mL aliquot of acetylene $\left(\mathrm{C}_{2} \mathrm{H}_{2}\right)$ gas was injected into the flask to replace the air with acetylene. The flasks containing roots with intact nodules were incubated at room temperature and 1.0-mL subsamples were analysed at 5 and $65 \mathrm{~min}$. The ARA value, in terms of $\mathrm{C}_{2} \mathrm{H}_{4}$ production per plant, was measured using a flame ionisation gas chromatograph (GC-14A, Shimadzu, Kyoto, Japan).

\subsection{Experiment II: Physicochemical Properties of Peat Soil and Biofertilizer Production Using the Peat Soil}

Peat soils were collected from Heho, Shan State, Myanmar. The collected peat soils were spread and air-dried at room temperature for $24 \mathrm{~h}$, then crushed by hand and sieved using a 2-mm mesh sieve. They were sterilised by autoclave at $120^{\circ} \mathrm{C}$ for $20 \mathrm{~min}$ before importing to Japan. They were stored at $4{ }^{\circ} \mathrm{C}$ until soil analysis. The soil $\mathrm{pH}_{\mathrm{H} 2 \mathrm{O}}\left(1: 2.5\right.$, soil: $\left.\mathrm{H}_{2} \mathrm{O}\right)$ was measured using a $\mathrm{pH}$ meter. To obtain the nutrient contents of the peat soil, samples were digested using the salicylic acid- $\mathrm{H}_{2} \mathrm{SO}_{4}$-hydrogen peroxide $\left(\mathrm{H}_{2} \mathrm{O}_{2}\right)$ digestion method [27]. Total $\mathrm{N}$ was determined using the indophenol method [28], and total phosphorus $(\mathrm{P})$ was analysed using the ascorbic acid method [29]. Mineralisable $\mathrm{N}$ was assessed using the soil incubation method [30]. The mineralisable $\mathrm{N}$ content was measured as described by Cataldo et al. [28]. Available P was measured using Truog's method [31]. Cation exchange capacity (CEC) and exchangeable cations were determined using the ammonium acetate shaking extraction 
method [32] followed by analysis using an atomic absorption spectrophotometer (Z-5300, Hitachi, Tokyo, Japan).

Inoculant preparation was conducted as described above. In this study, we used sterilised peat soil as the carrier. Peat soil was sterilised by autoclaving at $120^{\circ} \mathrm{C}$ for $20 \mathrm{~min}$ to kill all bacteria in the peat soil. First, $100 \mathrm{~g}$ of sterilised peat powder was placed into a polyethylene bag. Second, $20 \mathrm{~mL}$ of each Bradyrhizobium strain (B. japonicum SAY3-7 and B. elkanii BLY3-8) was added. Third, S. griseoflavus P4 spores from IMA-2 plates were added into the polyethylene bag. Then, the polyethylene bag was placed into a black polyethylene bag to protect the bacteria from the effects of light. The population densities of both bacteria were prepared to obtain a density of $10^{10}$ cells $\mathrm{g}^{-1}$. The water holding capacity of the biofertilizer was maintained at around $45 \%$. The packets were stored in an incubator at $30{ }^{\circ} \mathrm{C}$ in the dark. Aside from the biofertilizer packages, we prepared packages without added bacteria to check for contamination. Moreover, all materials used in biofertilizer production processes were sterilised, and all processes were performed on a clean bench to avoid contamination.

The survival of S. griseoflavus P4 was assessed using the plate counting method [33]. The survival of rhizobia in the sterilised peat soils was checked monthly using the most probable number (MPN) method [33] with Yezin-6 (non-Rj) as the host plant. For the MPN count, the soybean seeds were surface-sterilised. Then, $1 \mathrm{~mL}$ of each dilution from $10^{-1}$ to $10^{-10}$ was inoculated per seed. Plants were harvested at 4 weeks after sowing. Four replicate plants were used for each dilution. The quality of the biofertilizer was assessed every four months. The Yezin- 6 (non-Rj) soybean variety was used for quality assessment. Biofertilizer was diluted with autoclaved deionised water to $10^{-1}$ to $10^{-10}$. Then, each sterilised seed was inoculated with $5 \mathrm{~mL}$ of the biofertilizer suspension. Cultivation and data collection were as described above. This experiment was conducted from June 2017 to May 2018.

\subsection{Experiment III: Evaluation of Symbiotic Effectiveness of Biofertilizer on Yezin-3 $\left(R j_{4}\right)$ and Yezin-6 (non-Rj)} Soybean Varieties at Different Growth Stages

For pot preparation, an a/5000 Wagner pot was filled with $3.7 \mathrm{~kg}$ (oven dry basis) of Futsukaichi soil. Then, compound fertiliser containing 3\% nitrogen $(\mathrm{N}), 10 \%$ diphosphorus pentoxide $\left(\mathrm{P}_{2} \mathrm{O}_{5}\right)$, and $10 \%$ potassium oxide $\left(\mathrm{K}_{2} \mathrm{O}\right)$ was applied at the rate of $1.6 \mathrm{~g} \mathrm{pot}^{-1}$ at the time of pot preparation. The maximum water holding capacity was maintained at $60 \%$ at the time of sowing. The seed inoculation method used in this experiment was performed by mixing 100 soybean seeds with $10 \mathrm{~g}$ biofertilizer and $7 \mathrm{~mL} \mathrm{20 \%} \mathrm{liquid} \mathrm{solution} \mathrm{of} \mathrm{gum} \mathrm{arabic.} \mathrm{Four} \mathrm{inoculated} \mathrm{seeds} \mathrm{were} \mathrm{planted} \mathrm{per}$ pot and covered with soil just after seed sowing. At 20 days after sowing (DAS), thinning was performed to maintain one plant per pot. In this study, factorial design was used with three replications. This experiment was conducted from July 2017 to October 2017.

Plant samples were collected at three growth stages: V6 (six unfolded trifoliate leaves), R3.5 (early pod-fill stage), and R8 (maturity stage). At the V6 stage, ARA was measured as described above. At the R3.5 stage, relative ureide index (RUI) measurement was conducted on xylem sap. Plants were cut just beneath the cotyledonary nodes and inserted into a silicon tube. The xylem sap was collected within 1 $\mathrm{h}$ after cutting and stored at $-30{ }^{\circ} \mathrm{C}$ for long-term use. Amino $\mathrm{N}$ [34], $\mathrm{NO}_{3}-\mathrm{N}$ [35], and ureide- $\mathrm{N}$ [36] were analysed from the xylem sap. The RUI was calculated as follows [37]: RUI $(\%)=4 \times$ ureide-N/ $(4$ $\times$ ureide- $\mathrm{N}+$ amino- $\mathrm{N}+$ nitrate- $\mathrm{N}) \times 100$. The percentage of $\mathrm{N}$ derived from $\mathrm{N}$ fixation was calculated as follows [38]: $\mathrm{y}=21.3+0.67 \mathrm{x}$, where $\mathrm{y}$ is the RUI (\%) and $\mathrm{x}$ is the percentage of nitrogen derived from nitrogen fixation $(\% \mathrm{Ndf})$, respectively.

At the V6, R3.5, and R8 stages, the shoots were divided into leaves, stems and petioles, shells, unfilled seeds, and filled seeds to measure total N, P, K, Ca, and Mg contents. Each plant part was dried at $70{ }^{\circ} \mathrm{C}$ for $72 \mathrm{~h}$ and separately ground into a powder using a mill (100-120 mesh, Tecator $\mathrm{AB}$, Hoedanaes, Sweden). After digestion of the nutrients using the $\mathrm{H}_{2} \mathrm{SO}_{4}-\mathrm{H}_{2} \mathrm{O}_{2}$ digestion method, total $\mathrm{N}$ content was measured with the indophenol method and total $\mathrm{P}$ was analysed using the ascorbic acid method. Total K, Ca, and Mg were analysed by atomic absorption spectrophotometer (Z-5300, Hitachi). 


\subsection{Statistical Analysis}

Data were analysed using the STATISTIX 8 software package (Analytical Software, Tallahassee, FL, USA), and means were compared using Tukey's HSD test with a $P$-value $<0.05$ indicating statistical significance.

\section{Results}

3.1. Experiment I. Effect of Single, Dual and Combined Inoculation of SAY3-7, BLY3-8 and P4 on Ssymbiotic Effectiveness of Different Soybean Varieties

The results of plant growth, nodulation, and nitrogen fixation are shown in Table 1. Nodule numbers were not significantly different among treatments in Yezin-3 and Yezin-6 soybean varieties. However, nodule dry weight was significantly different among treatments in Yezin-3 and Yezin-6 soybeans. Single, dual, or combined inoculation showed no significant differences in root dry weight among the tested soybean varieties, but there were significant differences in shoot dry weight. Shoot dry weights of plants inoculated with SAY3-7 and BLY3-8 with P4 were higher than those of controls in Yezin-3 and Yezin-6. Nitrogen fixation in terms of $\mathrm{C}_{2} \mathrm{H}_{4}$ production was significantly different in all tested varieties. The nitrogen fixation values of the dual inoculation of SAY3-7 + BLY3-8 and the combined inoculation of SAY3-7 + BLY3-8 + P4 were significantly higher in Yezin-3 and Yezin-6 soybean varieties.

Table 1. Effect of inoculation of B. japonicum SAY3-7, B. elkanii BLY3-8 and S. griseoflavus P4 on nodule number (NN), nodule dry weight (NDW), shoot dry weight (SDW), root dry weight (RDW) and the acetylene reducing activity (ARA) of soybeans at 30 days after sowing.

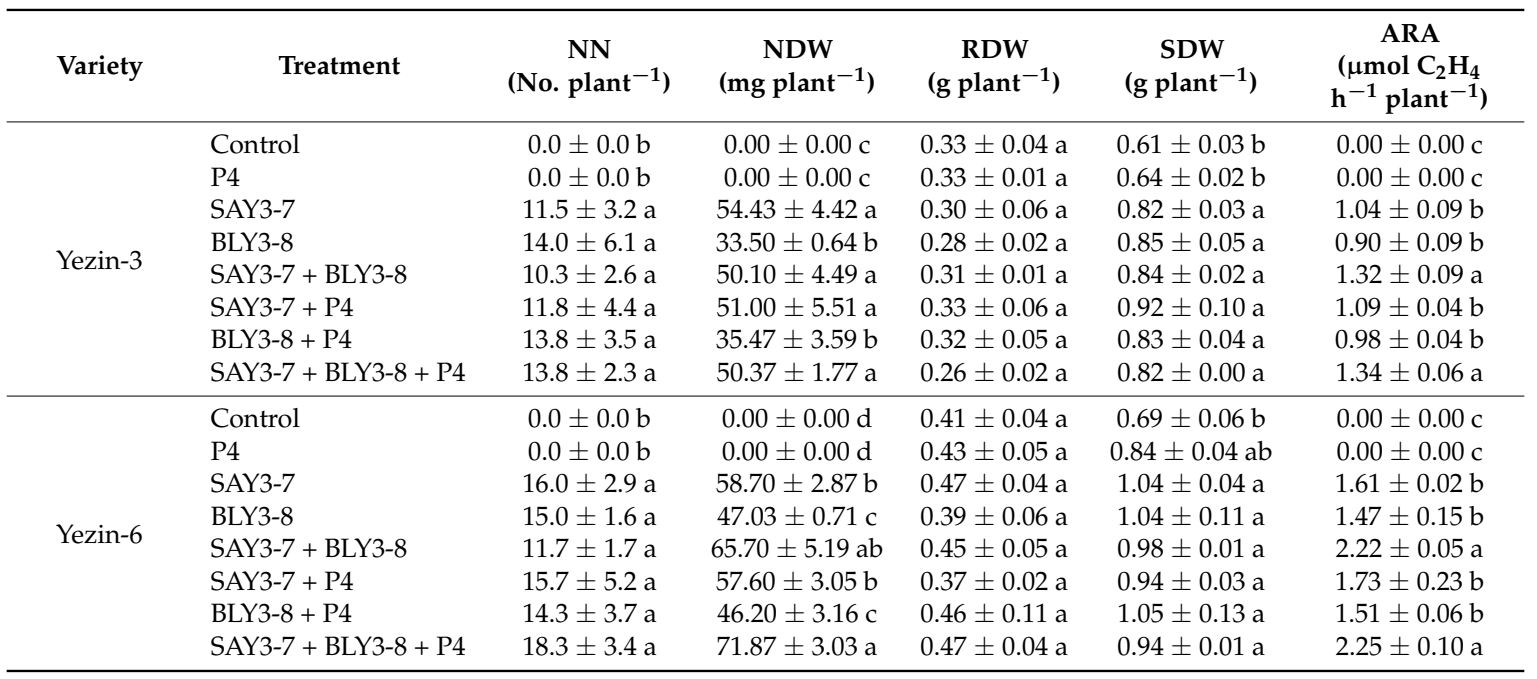

For each cultivar, mean values \pm SD with the same letters in each column are not significantly different at $p<0.05$ (Tukey's test).

\subsection{Expteriment II. Physicochemical Properties of Peat Soil and Biofertilizer Production Using the Peat Soil}

The physicochemical properties of the peat soil are described in Table 2. 
Table 2. Physicochemical properties of peat soil.

\begin{tabular}{lc}
\hline \multicolumn{1}{c}{ Physicochemical Properties } & Values \\
\hline Soil pH (Soil: $\left.\mathrm{H}_{2} \mathrm{O} ; 1: 2.5\right)$ & 7.11 \\
Total $\mathrm{N}(\%)$ & 0.80 \\
Total $\mathrm{P}_{2} \mathrm{O}_{5}(\%)$ & 0.09 \\
Available N (mg N/ $100 \mathrm{~g}$ soil) & 150.26 \\
Available $\mathrm{P}\left(\mathrm{mg} \mathrm{P}_{2} \mathrm{O}_{5} / 100 \mathrm{~g}\right.$ soil) & 4.25 \\
$\mathrm{CEC}\left(\mathrm{cmol}_{\mathrm{c}} \mathrm{Kg}^{-1}\right)$ & 20.47 \\
Exc. $\mathrm{Ca}\left(\mathrm{cmol}_{\mathrm{c}} \mathrm{Kg}^{-1}\right)$ & 25.61 \\
Exc. $\mathrm{Mg}\left(\mathrm{cmol}_{\mathrm{c}} \mathrm{Kg}^{-1}\right)$ & 1.08 \\
\hline
\end{tabular}

The populations of Bradyrhizobium strains and P4 on the peat soil were checked monthly. The results are presented in Table 3. The population of P4 decreased gradually to six months after producing the biofertilizer, but the population was maintained at $1 \times 10^{8} \mathrm{cfu}^{-1}$ to 12 months. However, the population of Bradyrhizobium did not decrease and was maintained at a density of $7 \times 10^{9}$ cells g $^{-1}(\mathrm{MPN})$ in the peat from the beginning to the end of production. This result indicates that the peat soil collected from Myanmar is a suitable substrate for biofertilizer production.

Table 3. Survival of P4 and Bradyrhizobium on peat soil.

\begin{tabular}{ccc}
\hline \multirow{2}{*}{ Months after Producing } & P4 & Bradyrhizobium \\
\cline { 2 - 3 } & $\begin{array}{c}\text { Plate Count } \\
\text { (cfu g }^{-1} \text { ) }\end{array}$ & $\begin{array}{c}\text { MPN } \\
\text { (Cells g }^{-1} \text { ) }\end{array}$ \\
\hline 1 & $1.7 \times 10^{10}$ & $7 \times 10^{9}$ \\
2 & $2 \times 10^{10}$ & $7 \times 10^{9}$ \\
3 & $3.2 \times 10^{11}$ & $7 \times 10^{9}$ \\
4 & $2.8 \times 10^{11}$ & $7 \times 10^{9}$ \\
5 & $4 \times 10^{10}$ & $7 \times 10^{9}$ \\
6 & $2 \times 10^{10}$ & $7 \times 10^{9}$ \\
7 & $1.2 \times 10^{9}$ & $7 \times 10^{9}$ \\
8 & $4 \times 10^{8}$ & $7 \times 10^{9}$ \\
9 & $3 \times 10^{8}$ & $7 \times 10^{9}$ \\
10 & $3 \times 10^{8}$ & $7 \times 10^{9}$ \\
11 & $1.8 \times 10^{8}$ & $7 \times 10^{9}$ \\
12 & $1 \times 10^{8}$ & $7 \times 10^{9}$ \\
\hline Bacterial population for Bradyrhizobium and $\mathrm{P} 4$ was $1 \times 10^{10}$ at the time of preparation.
\end{tabular}

Nodulation and nitrogen fixation efficiency of the bacteria from the biofertilizer were measured at 4,8 , and 12 months after producing the biofertilizer. The results are shown in Figure 1. Diluted biofertilizer until $10^{-3}$ proved more effective for nodulation and nitrogen fixation than the other treatments at 4,8 , and 12 months after producing the biofertilizer. 
(A)

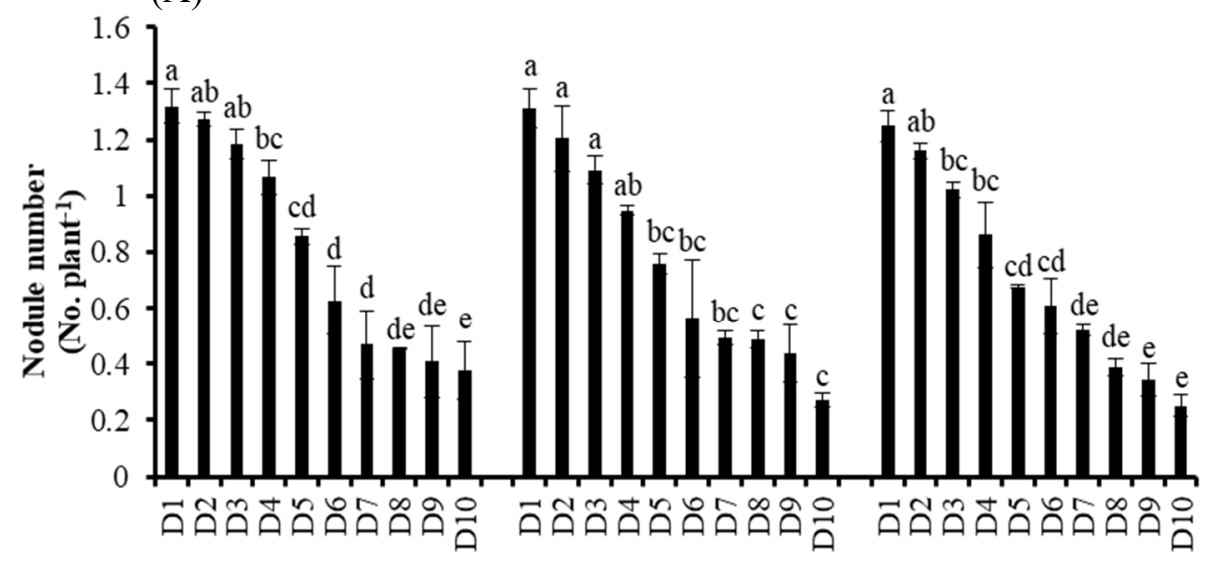

D1- $10^{-1}$
D2- $10^{-2}$
D3- $10^{-3}$
D4- $10^{-4}$
D5-10-5
D6-10-6
D7- $10^{-7}$
D8- $10^{-8}$
D9- $10^{-9}$

(B)

D $10-10^{-10}$

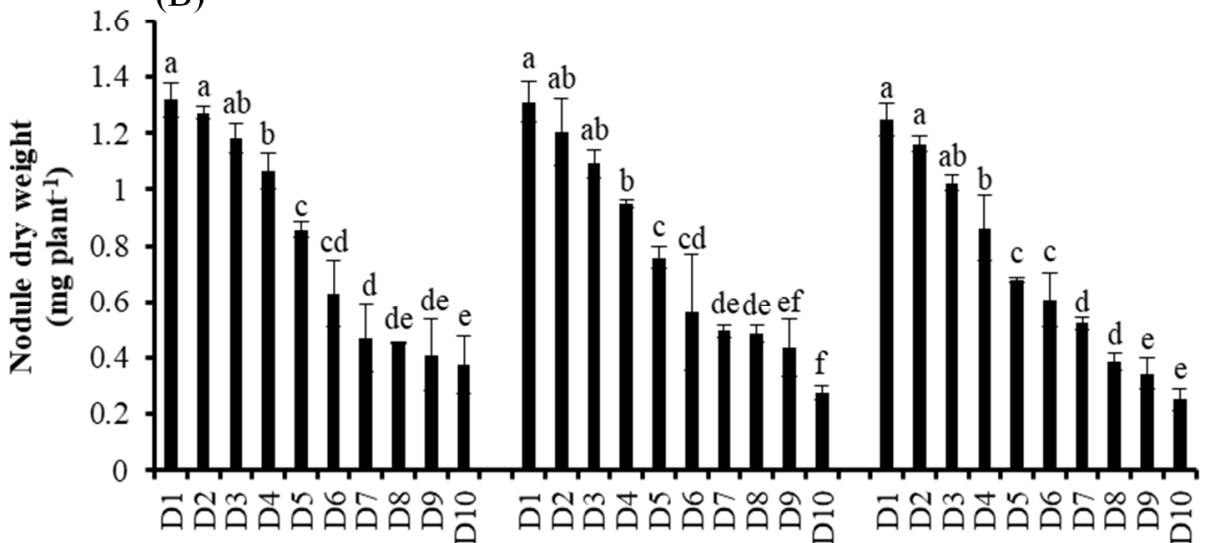

D $1-10^{-1}$

D2- $10^{-2}$

D3 $-10^{-3}$

D4- $10^{-4}$

D5- $10^{-5}$

D6- $10^{-6}$

D7- $10^{-7}$

D8 $-10^{-8}$

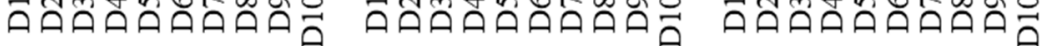

D9- $10^{-9}$

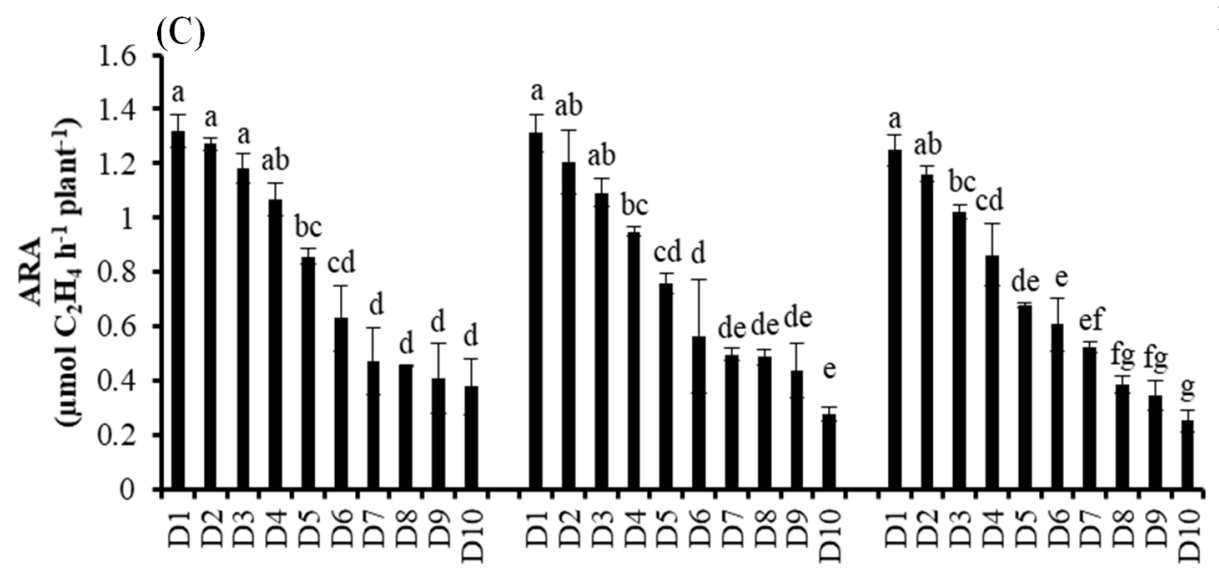

D $10-10^{-10}$

D1- $10^{-1}$

$\mathrm{D} 2-10^{-2}$

D $3-10^{-3}$

D4 $-10^{-4}$

D5- $10^{-5}$

D6- $10^{-6}$

D7- $10^{-7}$

D8 $-10^{-8}$

D9- $10^{-9}$

D $10-10^{-10}$

Figure 1. Effect of different dilution times of biofertilizer produced from B. japonicum SAY3-7 (type A), B. elkanii BLY3-8 (type B) and S. griseoflavus P4 on (A) nodule number, (B) nodule dry weight (C) nitrogen fixation in terms of ARA of Yezin-6 soybean varieties at 30 days after sowing. The histograms with the same letter are not significantly different at $p<0.05$ (Tukey's test). The bar on each histogram indicates SD.

3.3. Experiment III. Evaluation of Ssymbiotic Effectiveness of Biofertilizer on Yezin-3 $\left(\mathrm{Rj}_{4}\right)$ and Yezin-6 (non-Rj) Soybean Varieties at Different Growth Stages

The results of plant growth, nodulation, and nitrogen fixation for the Yezin-3 and Yezin-6 soybean varieties at V6 stage are shown in Table 4. Nodule number, nodule dry weight, and root dry weight were not significantly different between the Yezin-3 and Yezin-6 varieties at the V6 stage. However, 
shoot dry weight was significantly different between the two varieties. Shoot dry weight of Yezin-3 was significantly higher than that of Yezin-6. Moreover, inoculation with biofertilizer significantly improved nodule, root, and shoot dry weights in both varieties, but did not improve nodule number in either variety. There was no interaction effect between variety and treatment in any parameters at the V6 stage. Nitrogen fixation in terms of ARA was not significantly different between the Yezin-3 and Yezin- 6 varieties at the V6 stage. However, inoculation with biofertilizer resulted in significantly higher nitrogen fixation compared with control plants for both varieties. There was no interaction effect between variety and treatment on nitrogen fixation at the V6 stage.

Table 4. Effect of biofertilizer on plant growth, nodulation and nitrogen fixation in terms of ARA of Yezin-3 and Yezin-6 soybean varieties at V6 stage.

\begin{tabular}{|c|c|c|c|c|c|}
\hline Treatment & $\begin{array}{c}\text { NN } \\
\left(\text { No. } \text { plant }^{-1}\right)\end{array}$ & $\begin{array}{c}\text { NDW } \\
\left.\text { (mg plant }^{-1}\right)\end{array}$ & $\begin{array}{c}\text { RDW } \\
\left(\text { g plant }^{-1}\right)\end{array}$ & $\begin{array}{c}\text { SDW } \\
\left(\text { g plant }^{-1}\right)\end{array}$ & $\begin{array}{c}\text { ARA } \\
\left(\mu \mathrm{mol} \mathrm{C}_{2} \mathrm{H}_{4}\right. \\
\left.\mathrm{h}^{-1} \text { plant }^{-1}\right)\end{array}$ \\
\hline Yezin-3 & $10.3 \pm 1.7 \mathrm{~A}$ & $26.98 \pm 4.33 \mathrm{~A}$ & $0.46 \pm 0.07 \mathrm{~A}$ & $1.81 \pm 0.11 \mathrm{~A}$ & $0.62 \pm 0.12 \mathrm{~A}$ \\
\hline Yezin-6 & $12.2 \pm 2.1 \mathrm{~A}$ & $27.57 \pm 5.54 \mathrm{~A}$ & $0.47 \pm 0.06 \mathrm{~A}$ & $1.61 \pm 0.11 \mathrm{~B}$ & $0.60 \pm 0.15 \mathrm{~A}$ \\
\hline Biofertilizer & $12.7 \pm 1.9 \mathrm{a}$ & $31.00 \pm 0.73 \mathrm{a}$ & $0.51 \pm 0.04 \mathrm{a}$ & $1.91 \pm 0.05 \mathrm{a}$ & $0.73 \pm 0.01 \mathrm{a}$ \\
\hline \multicolumn{6}{|l|}{ Treatment of Yezin-6 } \\
\hline Control & $9.3 \pm 2.4 \mathrm{a}$ & $22.40 \pm 0.96 \mathrm{~b}$ & $0.41 \pm 0.01 \mathrm{~b}$ & $1.51 \pm 0.05 \mathrm{c}$ & $0.46 \pm 0.04 b$ \\
\hline Biofertilizer & $11.3 \pm 1.7 \mathrm{a}$ & $32.73 \pm 2.67 \mathrm{a}$ & $0.52 \pm 0.03 \mathrm{a}$ & $1.71 \pm 0.03 \mathrm{~b}$ & $0.73 \pm 0.07 \mathrm{a}$ \\
\hline \multicolumn{6}{|c|}{ Source of variance $(\operatorname{Pr}>F)$} \\
\hline $\mathrm{CV} \%$ & 8.64 & 9.34 & 4.67 & 2.79 & 8.64 \\
\hline
\end{tabular}

NN; nodule number, NDW; nodule dry weight, SDW; shoot dry weight, RDW; root dry weight, ARA; acetylene reducing activity. Mean values $\pm \mathrm{SD}$ with the same upper-case or lower-case letter in each column are not significantly different at $p<0.05$ (Tukey's test). ns: nonsignificant, ${ }^{* *}$ : significant at $p<0.01$.

The results of plant growth, nodulation, and nitrogen fixation of the Yezin-3 and Yezin-6 soybean varieties at the R3.5 stage are shown in Table 5. Nodule number and root dry weight were significantly different between the Yezin-3 and Yezin-6 varieties at the R3.5 stage, whereas nodule dry weight and shoot dry weight were not significantly different between the two varieties. Nodule number and root dry weight of Yezin-6 were significantly higher than those of Yezin-3. Inoculation of peat-based biofertilizer significantly improved nodule number in the Yezin-6 variety, but not in the Yezin-3 variety. Moreover, biofertilizer had significant effects on shoot dry weight in both varieties. There were no interaction effects between variety and treatment for nodule number, nodule dry weight, root dry weight, or shoot dry weight at the R3.5 stage. At R3.5, nitrogen fixation in terms of RUI(\%) and $\%$ Ndfa differed significantly between varieties and between treatments. Yezin-6 had more potential for nitrogen fixation than Yezin-3. Compared with the control, utilisation of biofertilizer had significant effects on RUI(\%) and \%Ndfa in both soybean varieties. There was an interaction effect between variety and treatment in RUI(\%) and \%Ndfa at the R3.5 stage. 
Table 5. Effect of biofertilizer on plant growth, nodulation and nitrogen fixation in terms of RUI (\%) and $\%$ Ndfa of Yezin-3 and Yezin- 6 soybean varieties at R3.5 stage.

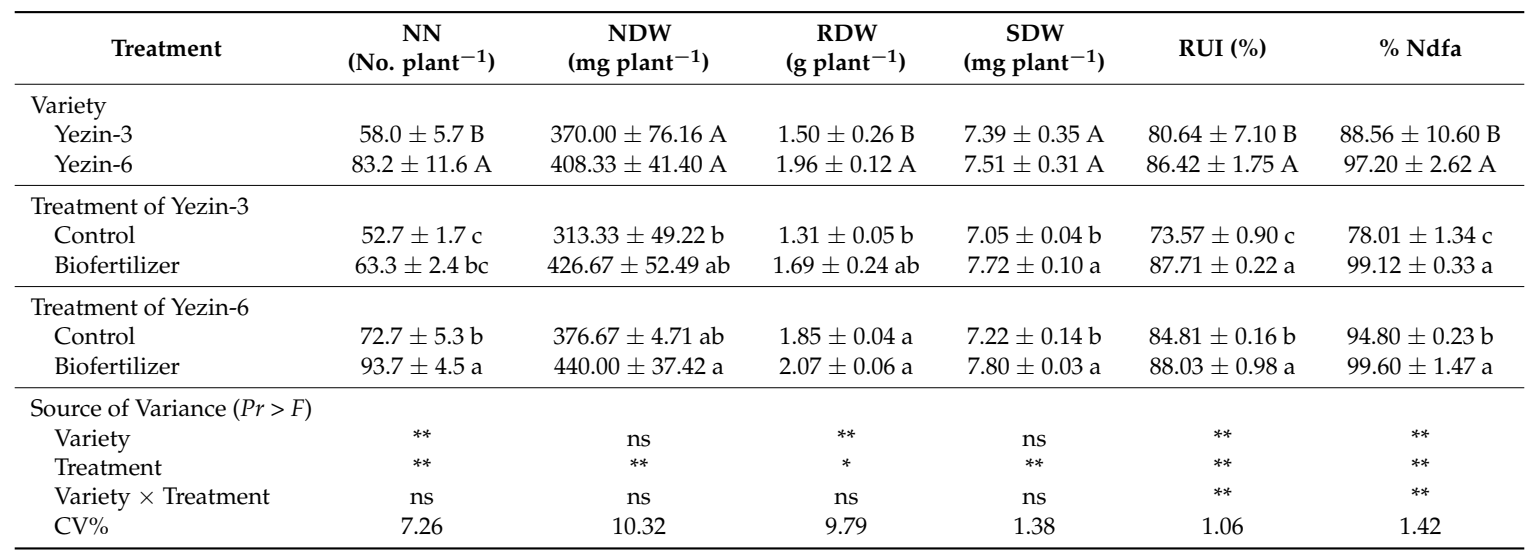

NN; nodule number, NDW; nodule dry weight, SDW; shoot dry weight, RDW; root dry weight, RUI (\%); relative ureide index $(\%), \% \mathrm{Ndfa}$; percentage of nitrogen derived from nitrogen fixation. Mean values $\pm \mathrm{SD}$ with the same upper-case or lower-case letter in each column are not significantly different at $p<0.05$ (Tukey's test). ns: nonsignificant, *: significant at $p<0.05,{ }^{* *}$ : significant at $p<0.01$.

The results of $\mathrm{N}, \mathrm{P}, \mathrm{K}, \mathrm{Ca}$, and $\mathrm{Mg}$ uptakes at the V6 stage are shown in Table 6. There were no significant differences in uptakes between the Yezin-3 and Yezin-6 varieties at the V6 stage. Application of biofertilizer did not significantly improve N, P, Ca, and Mg uptake in either variety, but biofertilizer increased $\mathrm{K}$ uptake in the Yezin-6 variety (but not in the Yezin-3 variety) compared with the control. There was no interaction effect between variety and treatment in nutrient uptakes at the V6 stage. The N, P, K, Ca, and Mg uptake results at the R3.5 stage are shown in Table 7. N, K, Ca, and Mg uptakes were significantly different between the Yezin-3 and Yezin- 6 varieties at the R3.5 stage. The $\mathrm{N}$ uptake of Yezin-3 was significantly higher than that of Yezin- 6 . In contrast to the $\mathrm{N}$ uptake, the $\mathrm{K}, \mathrm{Ca}$, and $\mathrm{Mg}$ uptakes of Yezin-3 were significantly lower than those of Yezin-6. Application of biofertilizer did not significantly improve $\mathrm{N}, \mathrm{K}$, and Ca uptakes in either variety, but application of biofertilizer increased $\mathrm{P}$ and $\mathrm{Mg}$ uptakes in both varieties compared with the control. There was no interaction effect between variety and treatment in nutrient uptakes at the R3.5 stage. The N, P, K, Ca, and $\mathrm{Mg}$ uptake results at the R8 stage are shown in Table 8. $\mathrm{N}$ and $\mathrm{K}$ uptakes were significantly different between the Yezin-3 and Yezin- 6 varieties at the R8 stage, but those of other nutrients were not different. The $\mathrm{N}$ and $\mathrm{K}$ uptakes of Yezin- 6 were significantly higher than those of Yezin-3. Application of biofertilizer significantly increased $\mathrm{N}$ and $\mathrm{K}$ uptakes in both varieties, but biofertilizer application did not increase $\mathrm{P}, \mathrm{Ca}$, and $\mathrm{Mg}$ uptakes at the $\mathrm{R} 8$ stage in either variety compared with control. There was no interaction effect between variety and treatment on the nutrient uptakes at the R8 stage. 
Table 6. Effect of biofertilizer on N, P, K, Ca and Mg uptakes of Yezin-3 and Yezin-6 soybean varieties at V6 stage.

\begin{tabular}{|c|c|c|c|c|c|}
\hline Treatment & $\begin{array}{c}\mathrm{N} \\
\left(\mathrm{mg} \mathrm{plant}^{-1}\right)\end{array}$ & $\frac{P}{\left(m g \text { plant }^{-1}\right)}$ & $\frac{\mathrm{K}}{\left(\mathrm{mg} \mathrm{plant}^{-1}\right)}$ & $\begin{array}{c}\text { Ca } \\
\left(\mathrm{mg} \mathrm{plant}^{-1}\right)\end{array}$ & $\begin{array}{c}\mathrm{Mg} \\
\left(\mathrm{mg} \mathrm{plant}^{-1}\right)\end{array}$ \\
\hline \multicolumn{6}{|l|}{ Varieties } \\
\hline Yezin-6 & $38.10 \pm 5.82 \mathrm{~A}$ & $1.12 \pm 0.11 \mathrm{~A}$ & $0.39 \pm 0.04 \mathrm{~A}$ & $0.37 \pm 0.04 \mathrm{~A}$ & $0.16 \pm 0.01 \mathrm{~A}$ \\
\hline \multicolumn{6}{|l|}{ Treatment of Yezin-3 } \\
\hline \multicolumn{6}{|l|}{ Treatment of Yezin-6 } \\
\hline Control & $32.82 \pm 2.41 \mathrm{ab}$ & $1.06 \pm 0.08 \mathrm{a}$ & $0.35 \pm 0.01 \mathrm{~b}$ & $0.38 \pm 0.03 \mathrm{a}$ & $0.16 \pm 0.01 \mathrm{a}$ \\
\hline Biofertilizer & $43.37 \pm 2.50 \mathrm{a}$ & $1.17 \pm 0.11 \mathrm{a}$ & $0.43 \pm 0.01 \mathrm{a}$ & $0.36 \pm 0.04 \mathrm{a}$ & $0.16 \pm 0.01 \mathrm{a}$ \\
\hline \multicolumn{6}{|c|}{ Source of Variance $(\operatorname{Pr}>F)$} \\
\hline
\end{tabular}

Mean values \pm SD with the same upper-case or lower-case letter in each column are not significantly different at $p<0.05$ (Tukey's test). ns: nonsignificant, ${ }^{* *}$ : significant at $p<0.01$.

Table 7. Effect of biofertilizer on N, P, K, Ca and Mg uptakes of Yezin-3 and Yezin-6 soybean varieties at R3.5 stage.

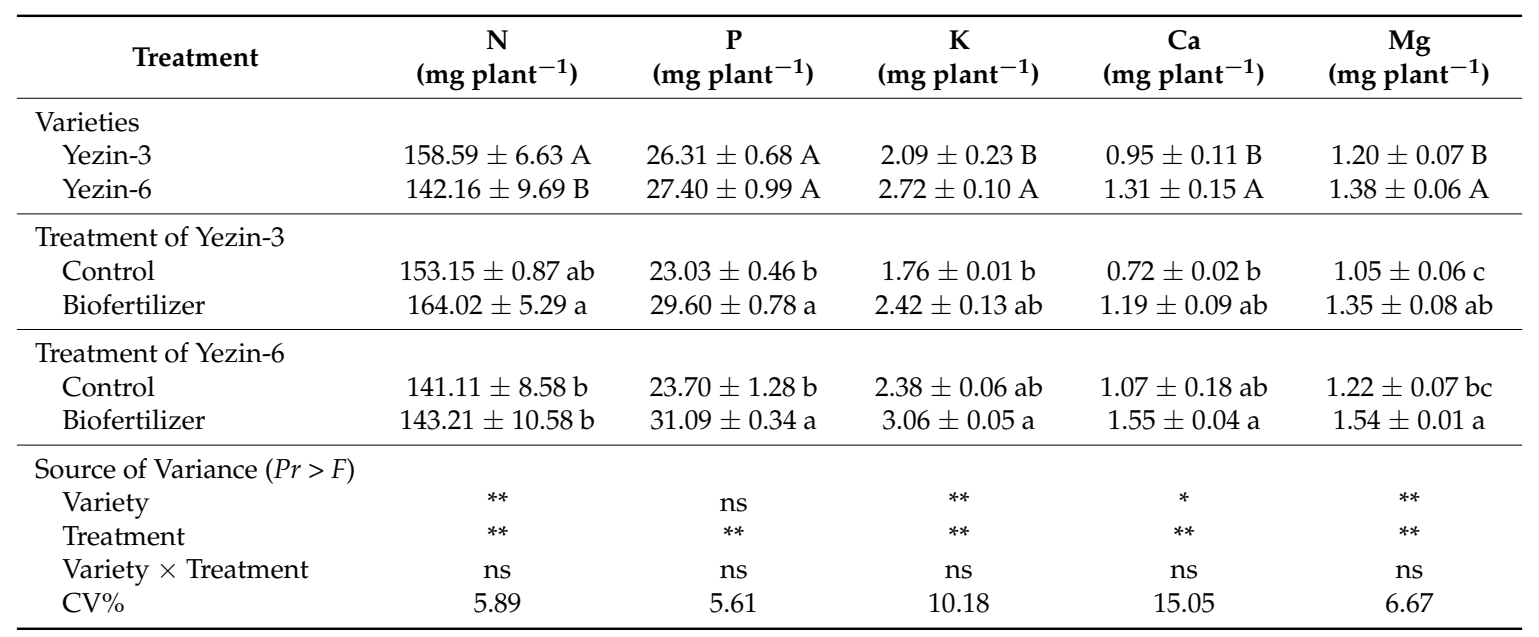

Mean values \pm SD with the same upper-case or lower-case letter in each column are not significantly different at $p<0.05$ (Tukey's test). ns: nonsignificant, ${ }^{*}$ : significant at $p<0.05,{ }^{* *}$ : significant at $p<0.01$. 
Table 8. Effect of biofertilizer on N, P, K, Ca and Mg uptakes of Yezin-3 and Yezin-6 soybean varieties at R8 stage.

\begin{tabular}{|c|c|c|c|c|c|}
\hline Treatment & $\frac{\mathrm{N}}{\left(\mathrm{mg} \mathrm{plant}^{-1}\right)}$ & $\frac{P}{\left(\mathrm{mg} \mathrm{plant}^{-1}\right)}$ & $\frac{\mathrm{K}}{\left(\mathrm{mg} \mathrm{plant}^{-1}\right)}$ & $\begin{array}{c}\text { Ca } \\
\left(\mathrm{mg} \mathrm{plant}^{-1}\right)\end{array}$ & $\begin{array}{c}\mathrm{Mg} \\
\left(\mathrm{mg} \mathrm{plant}^{-1}\right)\end{array}$ \\
\hline \multicolumn{6}{|l|}{ Varieties } \\
\hline Yezin-3 & $192.24 \pm 29.23 \mathrm{~B}$ & $9.87 \pm 3.43 \mathrm{~A}$ & $1.49 \pm 0.36 \mathrm{~B}$ & $1.29 \pm 0.25 \mathrm{~A}$ & $0.89 \pm 0.16 \mathrm{~A}$ \\
\hline Yezin-6 & $238.10 \pm 28.44 \mathrm{~A}$ & $9.87 \pm 3.92 \mathrm{~A}$ & $1.73 \pm 0.41 \mathrm{~A}$ & $1.41 \pm 0.30 \mathrm{~A}$ & $0.82 \pm 0.18 \mathrm{~A}$ \\
\hline \multicolumn{6}{|l|}{ Treatment of Yezin-3 } \\
\hline Control & $163.53 \pm 3.14 \mathrm{c}$ & $9.66 \pm 1.34 \mathrm{a}$ & $1.28 \pm 0.12 \mathrm{~b}$ & $1.21 \pm 0.11 \mathrm{a}$ & $0.87 \pm 0.07 \mathrm{a}$ \\
\hline Biofertilizer & $220.94 \pm 7.16 b$ & $10.08 \pm 0.44 \mathrm{a}$ & $1.70 \pm 0.14 \mathrm{a}$ & $1.38 \pm 0.03 \mathrm{a}$ & $0.90 \pm 0.2 \mathrm{a}$ \\
\hline \multicolumn{6}{|l|}{ Treatment of Yezin- 6} \\
\hline Control & $212.24 \pm 11.44 \mathrm{~b}$ & $9.54 \pm 1.78 \mathrm{a}$ & $1.64 \pm 0.29 \mathrm{a}$ & $1.34 \pm 0.15 \mathrm{a}$ & $0.78 \pm 0.11 \mathrm{a}$ \\
\hline Biofertilizer & $263.97 \pm 12.23 \mathrm{a}$ & $10.20 \pm 0.60 \mathrm{a}$ & $1.81 \pm 0.14 \mathrm{a}$ & $1.47 \pm 0.22 \mathrm{a}$ & $0.86 \pm 0.08 \mathrm{a}$ \\
\hline \multicolumn{6}{|c|}{ Source of Variance $(\operatorname{Pr}>F)$} \\
\hline Variety & $* *$ & ns & $* *$ & ns & ns \\
\hline Treatment & $* *$ & ns & $* *$ & ns & ns \\
\hline Variety $\times$ Treatment & ns & ns & ns & ns & ns \\
\hline $\mathrm{CV} \%$ & 4.26 & 8.21 & 5.84 & 10.03 & 8.34 \\
\hline
\end{tabular}

Mean values \pm SD with the same upper-case or lower-case letter in each column are not significantly different at $p<0.05$ (Tukey's test). ns: nonsignificant, ${ }^{* *}$ : significant at $p<0.01$.

The results of yield and yield components at the R8 stage are shown in Table 9. Inoculation of soybeans with biofertilizer produced significantly higher seed yield in Yezin- 6 than in the control, but not in Yezin-3. Moreover, the seed yield of Yezin-6 was significantly higher than that of Yezin-3. There were no interaction effects between variety and treatment on yield or yield-related parameters at the R8 stage.

Table 9. Effect of biofertilizer on yield and yield related parameters of Yezin-3 and Yezin-6 soybean varieties at R8 stage.

\begin{tabular}{|c|c|c|c|c|}
\hline Treatment & $\begin{array}{c}\text { Pods } \\
{\text { (No. } \text { plant }^{-1} \text { ) }}^{\text {Non }}\end{array}$ & $\begin{array}{l}\text { Seed Per Pod } \\
(\text { No. pod } \\
\text {-1) }\end{array}$ & $\begin{array}{l}100 \text { Seed Weight } \\
\text { (g) }\end{array}$ & 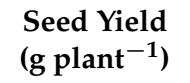 \\
\hline \multicolumn{5}{|l|}{ Variety } \\
\hline Yezin-3 & $20.8 \pm 3.0 \mathrm{~A}$ & $1.8 \pm 0.1 \mathrm{~A}$ & $13.48 \pm 0.95 \mathrm{~A}$ & $5.07 \pm 0.41 \mathrm{~B}$ \\
\hline Yezin-6 & $20.3 \pm 2.4 \mathrm{~A}$ & $1.9 \pm 0.1 \mathrm{~A}$ & $14.51 \pm 0.89 \mathrm{~A}$ & $5.84 \pm 0.59 \mathrm{~A}$ \\
\hline \multicolumn{5}{|l|}{ Treatment of Yezin-3 } \\
\hline Control & $19.3 \pm 1.7 \mathrm{a}$ & $1.8 \pm 0.1 \mathrm{a}$ & $13.75 \pm 0.71 \mathrm{a}$ & $4.66 \pm 0.06 \mathrm{~b}$ \\
\hline Biofertilizer & $22.3 \pm 3.3 \mathrm{a}$ & $1.9 \pm 0.1 \mathrm{a}$ & $13.22 \pm 1.07 \mathrm{a}$ & $5.31 \pm 0.11 b$ \\
\hline \multicolumn{5}{|l|}{ Treatment of Yezin- 6} \\
\hline Control & $18.7 \pm 1.9 \mathrm{a}$ & $2.0 \pm 0.1 \mathrm{a}$ & $14.31 \pm 0.93 \mathrm{a}$ & $5.47 \pm 0.25 b$ \\
\hline Biofertilizer & $22.0 \pm 1.4 \mathrm{a}$ & $2.0 \pm 0.1 \mathrm{a}$ & $14.71 \pm 0.80 \mathrm{a}$ & $6.36 \pm 0.30 \mathrm{a}$ \\
\hline \multicolumn{5}{|c|}{ Source of Variance $(\mathrm{Pr}>F)$} \\
\hline Variety & ns & ns & ns & $* *$ \\
\hline Treatment & ns & ns & ns & $* *$ \\
\hline Variety $\times$ Treatment & ns & ns & ns & ns \\
\hline $\mathrm{CV} \%$ & 13.57 & 7.95 & 7.86 & 5.22 \\
\hline
\end{tabular}

Mean values \pm SD with the same upper-case or lower-case letter in each column are not significantly different at $p<0.05$ (Tukey's test). ns: nonsignificant, ${ }^{* *}$ : significant at $p<0.01$.

\section{Discussion}

Biological nitrogen fixation (BNF) is an essential component of sustainable agriculture [38], and inoculant of rhizobia has been applied frequently as a biofertilizer. Biofertilizer is usually produced using Rhizobium species. However, in this study, Bradyrhizobium and Streptomyces species were used to produce biofertilizer because the presence of the biocontrol microorganism Streptomyces in the rhizosphere plays an essential role in enhancing the growth and development of useful bacteria, such as nitrogen-fixing bacteria [39]. Plant growth promotion can be induced by the function of a single 
bacterial strain and the synergistic functions of different bacterial species (Streptomyces sp. R170 with Sphingomonas sp. T168 or Methylibium sp. R182) [40]. The endophytic actinomycete strain, P4 used in this experiment was isolated from sweet pea root at Kurima, Tsu-City, Japan and its 16S rRNA sequence has $99.7 \%$ sequence identity with that of Streptomyces griseoflavus (Accession number: EU741217) [41]. In this study, nitrogen fixation was significantly increased by dual inoculation with B. japonicum SAY3-7 + B. elkanii BLY3-8 and also combined inoculation with B. japonicum SAY3-7 + B. elkanii BLY3-8 + S. griseoflavus P4 in all tested soybean varieties. The result was interesting in that different Bradyrhizobium species (B. japonicum SAY3-7 + B. elkanii BLY3-8) induced synergistic effects on nitrogen fixation. In contrast to the previous finding in which synergistic effects occurred due to co-inoculation of S. griseoflavus P4 with B. japonicum SAY3-7 or B. elkanii AHY3-1 [42], more synergistic effects on nitrogen fixation occurred with co-inoculation of different Bradyrhizobium species (B. japonicum SAY3-7 + B. elkanii BLY3-8). Based on the previous findings and those of the present study, we consider that the combination of B. japonicum SAY3-7 + B. elkanii BLY3-8 + S. griseoflavus P4 has potential for inoculant production.

Peat soil collected from Heho was used as a suitable carrier to produce the biofertilizer. Thein and Hein [43] reported that peat soil collected from Myanmar can be used as a suitable carrier, because the rhizobial population was maintained until 6 months after making the biofertilizer at local room temperatures $\left(30-32{ }^{\circ} \mathrm{C}\right)$. Our results were in agreement with their finding. Diluted biofertilizer until $10^{-3}$ improved nodulation and nitrogen fixation until 12 months after producing the biofertilizer. The inoculation density of biofertilizer diluted by factors of $10^{-1}, 10^{-2}$ and $10^{-3}$ contained $10^{8}, 10^{7}$, and $10^{6}$ cells, respectively. The incensement in nodulation and nitrogen fixation in the plants applied with diluted biofertilizer until $10^{-3}$ is might be due to the proper inoculation density. Many studies highlighted that nodulation of soybean was inhibited when inoculated with high density cell inoculum $\left(10^{9}\right.$ cell seed $\left.^{-1}\right)$ [44]. Yamakawa and Fukushima [45] reported that the application of a higher inoculum density decreased acetylene reduction activity $\left(10^{9}\right.$ cell seed $\left.^{-1}\right)$. There was also a significant increment in yield and nitrogen fixation observed at inoculation rates of $10^{5}$ and $10^{7}$ cells seed ${ }^{-1}$. Albareda et al. [46] stated that nodule dry weight, seed yield, and seed $\mathrm{N}$ content increased when the number of rhizobia applied to seeds was increased from $10^{4}$ to $10^{7}$ cell seed ${ }^{-1}$.

In this study, the plants with applied biofertilizer showed significant increases in shoot and root weight at the V6 and/or R3.5 stages. These findings are similar to those of our previous study, in which the combined use of $\mathrm{P} 4$ with Bradyrhizobium increased shoot and root biomass of soybeans [47]. This plant growth-promoting effect of $\mathrm{P} 4$ may be due to the secretion of growth-promoting hormones. The P4 used in biofertilizer manufacture can secrete the plant growth hormone indole acetic acid [47]. IAA controls many processes in plant growth and development and plays an important role in shaping plant root architecture, such as regulation of lateral root initiation, root vascular tissue differentiation, polar root hair positioning, root meristem maintenance and root gravitrophism [48]. In another experiment, Soe et al. [49] concluded that the Myanmar Bradyrhizobium strain and S. griseoflavus P4 will be useful as biofertilizer because of their synergy in plant growth, nodulation, and productivity of soybean. Our results confirmed that Bradyrhizobium strain and S. griseoflavus P4 could be produced as biofertilizer and we could see its effectiveness on soybean.

Our results showed that nodule number and/or nodule dry weight in plants with applied biofertilizer were significantly higher than those of the control plants at the V6 and/or R3.5 stages in the Yezin-3 and/or Yezin-6 soybean varieties. The soybean resulted in high nodule number and dry weight by Bradyrhizobium inoculant $[50,51]$ and single or mixed inoculants of Bradyrhizobium with Azotobacter chroococcum [52]. The use of biofertilizer produced from Bradyrhizobium strains and P4 increased nitrogen fixation in terms of ARA at the V6 stage and increased RUI(\%) and \%Ndfa at the R3.5 stage compared with uninoculated controls in both soybean varieties. It has been reported that the combined use of Bradyrhizobium with P4 induces higher nitrogenase activity in terms of ARA [53] and increased nitrogen fixation in terms of RUI(\%) and \%Ndfa [54] compared with uninoculated control. Symbiotic $\mathrm{N}$ fixation in soybeans can provide $40-70 \%$ of the total $\mathrm{N}$ requirement [55]. Soe et al. [56] 
found that co-inoculation with Streptomyces spp. P4 and indigenous Myanmar Bradyrhizobium was more effective for $\mathrm{N}$ uptake than single inoculation with Bradyrhizobium. In our previous study, $\mathrm{N}$, $\mathrm{P}, \mathrm{K}, \mathrm{Ca}$, and Mg uptakes were significantly improved by the combined use of SAY3-7 and P4 [20]. Moreover, N uptake was increased by the combined application of BLY3-8 and P4 [21]. Similarly, in the present study, the use of biofertilizer produced from SAY3-7, BLY3-8, and P4 significantly improved $\mathrm{N}, \mathrm{P}, \mathrm{K}, \mathrm{Ca}$, and $\mathrm{Mg}$ uptakes at some growth stages in Yezin-3 and Yezin-6 soybean varieties. The use of biofertilizer produced from Bradyrhizobium and P4 significantly increased seed yield in the Yezin-6 soybean variety compared with the control. These results support other findings from our group showing that the use of Bradyrhizobium strains with P4 increased seed yield of soybeans [57]. Combined inoculation of Rhizobium leguminosarum-PR1 with Pseudomonas sp. strain, PGERs17 also increases N, P and K uptakes of field pea (Pisum sativum L. variety VL Matar 42) compared with uninoculated control [58].

The legume-rhizobia symbiosis exhibits widely differing degrees of specificity. In some instances, the symbiosis is highly specific in that a particular species or strain of root nodule bacteria can induce an effective symbiosis association with only a particular legume specie or variety [59]. Senaratne et al. [60] reported that plant dry weight, nitrogen yield, percent nitrogen derived from the atmosphere and amount of nitrogen fixed were significantly influenced by specific combinations of host genotype and Bradyrhizobium strain. In our study, soybean variety also had influential effects on plant growth, nodulation, nitrogen fixation, and nutrient uptakes at some growth stages. This was in agreement with the findings of Soe et al. [54,56] and Soe and Yamakawa [57]. However, an interaction effect between variety and treatment occurred only on nitrogen fixation at the R3.5 stage, and not at the V6 stage or for any other parameters. This result supports the findings of others showing that biological nitrogen fixation in soybean can be increased by using effective Bradyrhizobium strains and efficient soybean cultivars [61].

\section{Conclusions}

According to the results of the tests prior to biofertilizer production, the combination of SAY3-7 + BLY3-8 + P4 has potential for inoculant production. During biofertilizer production, peat soil collected from Myanmar served as a suitable substrate for production, with the assurance of nodulation and nitrogen fixation in the Yezin-6 soybean variety. Moreover, the use of the biofertilizer produced from SAY3-7 + BLY3-8 + P4 was very effective in improving plant growth, nodulation, nitrogen fixation, nutrient uptakes, and productivity of the soybeans. Yezin- 6 is the more efficient variety for improved plant growth, nodulation, nitrogen fixation, nutrient absorption, and higher seed yield. Moreover, there was an interaction effect between variety and treatment only on nitrogen fixation in terms of RUI (\%) and \%Ndfa at the R3.5 stage, suggesting that nitrogen fixation can be increased by using an effective biofertilizer and an efficient soybean cultivar. It can be concluded that application of an effective biofertilizer and use of an efficient soybean variety are promising methods for promoting plant growth, nodulation, nitrogen fixation, and seed yield.

Author Contributions: Conceptualization, A.Z.H. and T.Y.; methodology and investigation, A.Z.H., S.M.M., K.M., data organization and formal analysis, A.Z.H.; writing—original draft preparation, A.Z.H.; writing-review and editing, S.M.M., K.M.; supervision, T.Y.; and all authors read and approved the manuscript.

Funding: This research and APC were granted by the Ministry of Education, Culture, Sports, Science, and Technology Grant Number: [130287].

Acknowledgments: We are thankful to Ministry of Education, Culture, Sports, Sciences and Technology (MEXT) of Japan for their financial support of the present study.

Conflicts of Interest: There is no financial support or relationships that may pose conflict of interest. 


\section{References}

1. Vessey, J.K. Plant growth promoting rhizobacteria as bio-fertilizers. Plant Soil 2003, 255, 571-586. [CrossRef]

2. Mazid, M.; Khan, T.A. Future of bio-fertilizers in Indian agriculture: An overview. Int. J. Agric. Food Res. 2015, 3, 10-23. [CrossRef]

3. DAR. Rhizobium biofertilizer. In The Result of Research of Agricultural Research, Golden Jubilee; Department of Agricultural Research: Yezin, Myanmar, 2004; pp. 114-118.

4. Schroth, M.N.; Hancock, J.G. Selected topics in biological control. Ann. Rev. Microbiol. 1981, 35, 453-476. [CrossRef] [PubMed]

5. Weller, D.M. Biological control of soil borne plant pathogens in the rhizosphere with bacteria. Ann. Rev. Phytopathol. 1988, 26, 379-407. [CrossRef]

6. Bharathi, V.; Sudhakar, R.; Parimala, K.; Reddy, V.A. Evaluation of bioagents and biofertilizers for the management of seed and seedling diseases of Sesamum indicum (Sesame). eSci. J. Plant Pathol. 2013, 2, 179-186.

7. Lehr, N.A.; Schrey, S.D.; Hampp, R.; Tarkka, M.T. Root inoculation with a forest soil. Streptomycete leads to locally and systemically increased resistance against phytopathogens in Norway Spruce. New Phytol. 2008, 177, 965-976. [PubMed]

8. Rothrock, C.S.; Gottlieb, D. Role of antibiosis in antagonism of Streptomyces hygroscopicus var. Geldans to Rhizoctonia solani in Soil. Can. J. Microbiol. 1984, 30, 1440-1447. [CrossRef]

9. Compant, S.; Duffy, B.; Nowak, J.; Clement, C.; Barka, E.A. Use of plant growth-promoting bacteria for biocontrol of plant diseases: Principles, mechanisms of action, and future prospects. Appl. Environ. Microbiol. 2005, 71, 4951-4959. [CrossRef]

10. Herridge, D.; Maw, J.B.; Thein, M.M.; Rupela, O.P.; Boonkerd, N.; Thao, T.Y.; Deaker, R.; Hartley, E.; Gemell, G. Expanding production and use of legume inoculants in Myanmar and Vietnam. In Proceedings of the 14th Australian Agronomy Conference, Adelaide, Australia, 21-25 September 2008.

11. Than, M.M.; San, K.K.; Thein, M.M. Evaluation of effective rhizobial strains for commercial legume inoculants. J. Agric. For. Livest. Fish. Sci. 2006, 6, 264-280.

12. Topre, S.D.; Panikar, S.S.; Mahajani, S.U. Biofertilizer: A novel approach for agriculture. J. Agric. Biotechnol. Sustain. Dev. 2011, 3, 205-208.

13. Mahanty, T.; Bhattacharjee, S.; Goswami, M.; Bhattacharyya, P.; Das, B.; Ghosh, A.; Tribedi, P. Biofertilizers: A potential approach for sustainable agriculture development. Environ. Sci. Pollut. Res. 2107, 24, 3315-3335. [CrossRef]

14. Than, H.; Aung, N.N.; Kyi, P.P. Response of rhizobial peat inoculants on five important legumes. In Proceedings of the 18th Congress Myanmar Agricultural Science Research Division, Yezin, Myanmar, 1987; pp. 1-12.

15. Smith, D.L.; Hume, D.J. Comparison of assay methods for $\mathrm{N}_{2}$ fixation utilizing white bean and soybean. Can. J. Plant Sci. 1987, 67, 11-19. [CrossRef]

16. Ishizuka, J.; Suemasu, Y.; Mizogami, K. Preference of Rj-soybean cultivars for Bradyrhizobium japonicum for nodulation. Soil Sci Plant Nutr. 1991, 37, 15-21. [CrossRef]

17. Ishizuka, J.; Yokoyama, A.; Suemasu, Y. Relationship between serotypes of Bradyrhizobium japonicum and their compatibility with Rj-cultivars for nodulation. Soil Sci Plant Nutr. 1991, 37, 23-30. [CrossRef]

18. Htwe, A.Z.; Saeki, Y.; Moe, K.; Yamakawa, T. Determining nodulation regulatory (Rj) genes Myanmar soybean cultivars and their symbiotic effectiveness with Bradyrhizobium japonicum USDA110. Am. J. Plant Sci. 2015, 6, 2799-2810. [CrossRef]

19. Soe, K.M.; Yamakawa, T.; Hashimoto, S.; Sarr, P. Phylogenetic diversity of indigenous soybean bradyrhizobia from different agro-climatic regions in Myanmar. Sci. Asia 2013, 39, 574-583.

20. Htwe, A.Z.; Moh, S.M.; Moe, K.; Yamakawa, T. Effects of co-inoculation of Bradyrhizobium japonicum SAY3-7 and Streptomyces griseoflavus $\mathrm{P} 4$ on plant growth, nodulation, nitrogen fixation, nutrient uptake, and yield of soybean in a field condition. Soil Sci. Plant Nutr. 2018, 64, 222-229. [CrossRef]

21. Htwe, A.Z.; Moh, S.M.; Moe, K.; Yamakawa, T. Effects of co-inoculation of Bradyrhizobium elkanii BLY3-8 and Streptomyces griseoflavus P4 on $R j_{4}$ soybean varieties. Soil Sci. Plant Nutr. 2018, 64, 449-454. [CrossRef]

22. Nakano, Y.; Yamakawa, T.; Ikeda, M.; Ishizuka, J. Nodulation of Rj-soybean varieties with Rhizobium fredii USDA193 under limited supply of nutrients. Soil Sci. Plant Nutr. 1997, 43, 929-932. [CrossRef] 
23. Htwe, A.Z.; Yamakawa, T.; Sarr, P.S.; Sakata, T. Diversity and distribution of soybean-nodulation bradyrhizobia isolated from major soybean-growing regions in Myanmar. Afr. J. Microbiol. Res. 2015, 9, 2183-2196.

24. Kuykendall, L.D. Isolation and identification of genetically marked strains of nitrogen-fixing microsymbionts of soybeans. In Practical Symbiotic Nitrogen Fixation Methodology; Elkan, G.H., Ed.; Marcel Dekker: New York, NY, USA, 1987; pp. 205-220.

25. Shimizu, M.; Nakagawa, Y.; Sato, Y.; Furumai, T.; Igarashi, Y.; Onaka, H.; Yoshida, R.; Kunoh, H. Studies on endophytic actinomycetes (I) Streptomyces sp. isolate from rhododendron and its antifungal activity. J. Gen. Plant Pathol. 2000, 66, 360-366. [CrossRef]

26. Haider, J.; Hussam, A.K.M.A.; Ikeda, M.; Yamakawa, T.; Ishizuka, J. Effects of nitrate application on growth, nodulation and nitrogen fixation of nitrate-tolerant mutant soybean. Soil Sci. Plant Nutr. 1991, 37, 521-529. [CrossRef]

27. Ohyama, T.; Ito, M.; Kobayashi, K.; Araki, S.; Yasuyoshi, S.; Sasaki, O.; Yamazaki, T.; Soyama, K.; Tanemura, R.; Mizuno, Y.; et al. Analytical procedures of N, P, K contents in plant and manure materials using $\mathrm{H}_{2} \mathrm{SO}_{4}-\mathrm{H}_{2} \mathrm{O}_{2}$ Kjeldahl digestion method. Jpn. Bull. Facul. Agric. Niigata Univ. 1991, 43, 110-120.

28. Cataldo, D.A.; Schrader, L.E.; Youngs, V.L. Analysis by digestion and colrimetric assay of total nitrogen in plant tissues high in nitrate. Crop Sci. 1974, 14, 854-856. [CrossRef]

29. Murphy, J.; Riley, J.P. A modified single solution for the determination of phosphate in natural waters. Anal. Chim. Acta 1962, 27, 31-36. [CrossRef]

30. Sahrawat, K.L. Nitrogen availability indexes for submerged rice soils. Adv. Agron. 1983, 36, 415-451.

31. Truog, E. The determination of the readily available phosphorus in soils. J. Am. Soc. Agron. 1930, 22, 874-882. [CrossRef]

32. Muramoto, J.; Goto, I.; Ninaki, M. Rapid analysis of exchangeable cation and cation exchange capacity (CEC) of soils by shaking extraction method. Soil Sci Plant Nutr. 1992, 63, 210-215.

33. Somasegaran, P.; Hoben, H.J. Methods in Legume-Rhizobium Technology. Available online: https://www. ctahr.hawaii.edu/bnf/Downloads/Training/Rhizobium\%20technology/Title\%20Page.PDF (accessed on 12 February 2019).

34. Moore, S.; Stein, W.H. A Modified ninhydrin reagent for the photometric determination of amino acids and realted compounds. J. Biol. Chem. 1954, 211, 907-913.

35. Cataldo, D.A.; Haroon, M.; Schrader, L.E.; Youngs, V.L. Rapid colorimetric determination of nitrate in plant tissue by nitration of salicylic acid. Commun. Soil Sci. Plant Anal. 1975, 6, 71-80. [CrossRef]

36. Young, E.G.; Conway, C.F. On the estimation of Allantoin by the Rimini-Schryver reaction. J. Biol. Chem. 1942, 142, 839-853.

37. Herridge, D.F.; Peoples, M.B. Ureide assay for measuring nitrogen fixation by nodulated soybean calibrated by $15 \mathrm{~N}$ methods. Plant Physiol. 1990, 93, 495-503. [CrossRef] [PubMed]

38. Sessitsch, A.; Howieson, J.G.; Perret, X.; Antoun, H.; Martínez-Romero, E. Advances in rhizobium research. Crit. Rev. Plant Sci. 2002, 21, 323-378. [CrossRef]

39. Doolotkeldieva, T.; Bobusheva, S.; Konurbaeva, M. Effects of Streptomyces biofertilizer to soil fertility and rhizosphere's functional biodiversity of agricultural plants. Adv. Microbiol. 2015, 5, 555-571. [CrossRef]

40. Santiago, C.D.; Yagi, S.; Ijima, M.; Nashimoto, T.; Sawada, M.; Ikeda, S.; Asano, K.; Orikasa, Y.; Ohwada, T. Bacterial compatibility in combined inoculations enhances the growth of potato seedlings. Microbes Environ. 2017, 32, 14-23. [CrossRef]

41. Tang-um, J.; Niamsup, H. Chitinase production and antifungal potential of endophytic Streptomyces strain P4. Maejo Int. J. Sci. Technol. 2012, 6, 95-104.

42. Htwe, A.Z.; Yamakawa, T. Enhanced plant growth and/or nitrogen fixation by leguminous and non-leguminous crops after single or dual inoculation of Streptomyces griseoflavus P4 with Bradyhizobium strains. Afr. J. Microbiol. Res. 2015, 9, 2337-2344.

43. Thein, M.M.; Hein, M. Rhizobial inoculants production and their on-farm use in Myanmar. Extending nitrogen fixation research to farmer's fields. In Proceedings of the International Workshop on Managing Legume Nitrogen Fixation in The Cropping Suystems of Asia, Hyderabad, India, 20-24 August 1996.

44. Jitacksorn, S.; Sadowsky, M.J. Nodulation gene regulation and Quorum sensing control density- dependent suppression and restriction of nodulation in the Bradyrhizobium japonicum-soybean symbiosis. Appl. Environ. Microbiol. 2008, 74, 3749-3756. [CrossRef] 
45. Yamakawa, T.; Fukushima, Y. Low inoculum densities of Bradyrhizobium japonicum USDA110 is effective on production of soybean (Glycine max L. Merr.) cultivar Fukuyutaka.). J. Faculty Agric. Kyushu Univ. 2014, 59, 45-53.

46. Albareda, M.; Rodrı'guez-Navarro, D.N.; Temprano, F.J. Soybean inoculation: Dose, N fertilizer supplementation and rhizobia persistence in soil. Field Crops Res. 2009, 113, 352-356. [CrossRef]

47. Soe, K.M.; Yamakawa, T. Evaluating the effects of Streptomyces griseoflavus P4 on dry weight of different crops and examine phytohormones activity in term of indole acdic acid (IAA) production. Myanmar Agric. Res. J. 2018, 4, 165-17145.

48. Fukaki, H.; Okushima, Y.; Tasaka, M. Auxin-mediated lateral root formation in higher plants. Int. Rev. Cytol. 2007, 256, 111-137.

49. Soe, K.M.; Myint, S.S.; Win, M.M.; Aung, T.T.; San, K.K.; Myint, S.S. Co-inoculation of Myanmar Bradyrhizobium yuanmingense MAS34 and Streptomyces griseoflavus P4 inoculants to improve plant Growth, seed Yield of soybean cultivars and soil fertility improvement. Myanmar Agric. Res. J. 2018, 4, 154-164.

50. Ntambo, M.S.; Chilinda, I.S.; Taruvinga, A.; Hafeez, S.; Anwar, T.; Sharif, R.; Chambi, C.; Kies, L. The effect of rhizobium inoculation with nitrogen fertilizer on growth and yield of soybeans (Glycine max L.). Int. J. Biosci. 2017, 10, 163-172.

51. Ulzen, J.; Abaidoo, R.C.; Mensah, N.E.; Masso, C.; AbdelGadir, A.H. Bradyrhizobium inoculants enhance grain Yields of soybean and cowpea in Northern Ghana. Front. Plant Sci. 2016, 7, 1770. [CrossRef]

52. Kozieł, M.; Gebala, B.; Martyniuk, S. Response of soybean to seed inoculation with Bradyrhizobium japonicum and with mixed inoculants of B. japonicum and Azotobacter chroococcum. Pol. J. Microbiol. 2013, 62, 457-460. [PubMed]

53. Soe, K.M.; Yamakawa, T. Evaluation of effective Myanmar Bradyrhizobium strains isolated from Myanmar soybean and effects of coinoculation with Streptomyces griseoflavus P4 for nitrogen fixation. Soil Sci. Plant Nutr. 2013, 59, 361-370. [CrossRef]

54. Soe, K.M.; Bhromsiri, A.; Karladee, D.; Yamakawa, T. Effects of endophytic actinomycetes and Bradyrhizobium japonicum strains on growth, nodulation, nitrogen fixation and seed weight of different soybean varieties. Soil Sci. Plant Nutr. 2012, 58, 319-325. [CrossRef]

55. Klubeck, B.P.; Hendrickson, L.L.; Zablotowicz, R.M.; Skwara, J.E.; Varsa, E.C.; Smith, S.; Isleib, T.G.; Maya, J.; Valdes, M.; Dazzo, F.B.; et al. Competitiveness of selected Bradyrhizobium japonicum strains in Midwestern USA soils. Soil Sci. Soc. Am. J. 1988, 52, 662-666. [CrossRef]

56. Soe, K.M.; Bhromsiri, A.; Karladee, D. Effect of selected endophytic actinomycetes (Steptomyces sp.) and bradyrhizobia from Myanmar on growth, nodulation, nitrogen fixation and yield of different soybean varieties. CMU J. Nat. Sci. 2010, 9, 95-109.

57. Soe, K.M.; Yamakawa, T. Low-density co-inoculation of Myanmar Bradyrhizobium yuanmingense MAS34 and Streptomyces griseoflavus $\mathrm{P} 4$ to enhance symbiosis and seed yield in soybean varieties. Am. J. Plant Sci. 2013, 4, 1879-1892. [CrossRef]

58. Mishra, P.K.; Bisht, S.C.; Mishra, S.; Selvakumar, G.; Bisht, J.K.; Gupta, H.S. Coinoculation of Rhizobium Leguminosarum-PR1 with a cold tolerant Pseudomonas sp. improves iron acquisition, nutrient uptake and growth of filed pea (Pisum Sativum L.). J. Plant Nutr. 2012, 35, 243-256. [CrossRef]

59. Somasegaran, P.; Hoben, H.J. Handbook for Rhizobia: Methods in Legumes-Rhizobium Technology; Springer: New York, NY, USA, 1994; pp. 1-450.

60. Senaratne, R.; Amornpinol, C.; Hardarson, G. Effect of combined nitrogen on nitrogen fixation of soybean (Glycine max L. Merril) as affected by cultivar and rhizobial strain. Plant Siol 1987, 103, 45-50. [CrossRef]

61. Htwe, A.Z.; Yamakawa, T.; Moe, K.; Dien, D.C. Symbiotic effectiveness of different indigenous Bradyrhizobium strains on selected Rj-genes harboring Myanmar soybean cultivars. Afr. J. Microbiol. Res. 2015, 9, 2345-2353.

(C) 2019 by the authors. Licensee MDPI, Basel, Switzerland. This article is an open access article distributed under the terms and conditions of the Creative Commons Attribution (CC BY) license (http:// creativecommons.org/licenses/by/4.0/). 